\author{
Agnieszka Lisowska \\ University of Wroclaw \\ Institute of Geography and Regional Development \\ Socio-Economic Geography Institution \\ agnieszka.lisowska2@uwr.edu.pl
}

\title{
CRIME IN TOURISM DESTINATIONS: RESEARCH REVIEW
}

\begin{abstract}
Tourism has become a common phenomenon, very important for various reasons, especially for developing regions and countries, and which in consequence has been perceived as positive. However, increasingly commonly works have cast a slightly different look. Tourism leads to a temporarily increased number of people in a relatively small area, and contributes to the introduction of 'strangers' to local communities which can lead to problems such as crime. On the other hand, a higher risk of being a victim may lead to the reduced attractiveness of a given destination. A small number of studies in this field draw attention to this, concentrating on a general outline of their interdependence but specific urban tourist areas are rarely the subject of research. This review covers various works on the relationship between tourism and crime.
\end{abstract}

Keywords: crime, tourism, tourism crime, tourist destination, sense of security, threat of crime.

\section{INTRODUCTION}

There is no doubt that tourism has become a widespread phenomenon and has become available for almost everybody as social mobility and income have increased, and working patterns have changed. What is more, being an important economic sector stimulating the development of 'economically backward' countries and regions, it was mainly considered to have only positive effects. It was not until the turn of the 1970s that research in this area intensified and began to present some negative effects of tourism development. Initially, analyzes concerned only the over-exploitation of the natural environment, but the phenomenon, as a multi-faceted one, soon became a matter of interest to other disciplines which led to a variety of studies. A particularly important phenomenon in places of tourist reception is crime. More and more often it is seen as a result of crowding large groups of people into relatively small areas and, on the other hand, as a deterrent for potential tourists.

Taking into consideration both phenomena in the modern world, research into the level of security in the tourist parts of cities has attracted attention. Crime, as a difficult issue to analyze, has led to relatively few academic studies in areas of tourist reception. Due to the importance of security issues, this study presents a review of research into the connection between tourism and crime, and the influence of both to each other at various levels. This kind of research, treating issues more broadly, results mainly from the character of the problem and the research conducted so far. It should be underlined that there is relatively little research on urban tourist areas; however, existing ones provide substantive findings on the relationship.

As mentioned above, crime research is quite complex, as is the analysis of tourism flows, proved by the availability and the form of statistical data. Statistics on issues connected with tourism are collected by the Centre of Sport and Tourism Statistics, the Institute of Tourism in Warsaw School of Tourism and Hospitality Management, the Local Data Bank - a database run by Rzeczpospolita, and by the Ministry of Sport and Tourism of the Republic of Poland. However, the provided data mostly concern arrivals to Poland, journeys made by Poles, the expenditure of local governments on tourism, and information about accommodation facilities: their usage, equipment, and catering facilities. In most cases, the statistics are aggregated at the level of macro-regions, provinces, sub-regions and districts, whereas only some concern cities.

In the case of crime, the detailed data are aggregated mainly by provincial police headquarters and there made available on request. Information about the scale at national or province level is accessible on 
the websites of National Police Headquarters and Central Statistical Office. S. MORDWA (2013) points out that crime statistics do not cover all actual offences; thus, none of the institutions provides full data. This state of affairs allows two types of crime to be defined, crimes which are reported and detected by the authorities, and 'hidden' crimes. Only knowledge of the scale of both types gives a real picture. Available crime statistics allow an analysis of the extent of crime:

a) recorded, i.e. the number of offences passed on by the law enforcement authorities to a higher stage;

b) stated, i.e. the number of offences confirmed as crimes;

c) detected, i.e. the number of offences claimed as crimes, in which the offenders were detected and charged;

d) 'judged', i.e. the number of offences which have been legally recognized as crimes.

This way of perceiving crime raises a problem called the funnel effect, connected with the fact that the higher the phase, the lower number of offences and offenders in the statistics. The attention of researchers is focused mainly on the procedures and their credibility, and to a lesser extent on the problem itself.

What is more and should be borne in mind, the same behaviour does not have to be illegal in every country. It may turn out that an act which is considered a crime in one country is not treated as such in another (SZTAUDYNGER 2004). This is important in the case of tourism when different countries are compared.

The data aggregated in this way determines a particular way of conducting the analysis. Authors have different approaches. In some studies, specific regions or countries are a priori treated as 'tourist' and the crime rate is examined there. Whereas, in others attention is focused on the 'feelings' of tourists and the research is conducted using questionnaires in which interviewees are asked about their feeling of security, motives for decision making and the issues connected with criminal experience. It is evident that in both cases there are no adequate data which could easily support assumptions.

Accordingly, most of the studies are based on previously accepted paradigms and criminal behaviour is analyzed at different levels of reference. The most common theories used for analysis at the individual level are the biological, psychological, biosocial, psychosocial and some sociological theories (e.g. the theory of social learning, tension and control). Certain features (e.g. neurochemical or chemical imbalance, low sensitivity or defects of the nervous system, impulsivity, low self-control) define the individual as a potential offender. The following theories are mentioned at the macro-social level - social dis- organization, anomie, structural tensions, cultural conflicts, ecological, social learning and control. The magnitude increases with the intensification of the processes of economic development, modernization, social mobility, increased unemployment, economic diversification of society, normative chaos and others (BŁACHUT 2007).

Spatial and tempero-spatial aspects are also important in crime research. The attention of the researchers is focused mainly on the following issues - why the intensity is higher in the given area at a given time, and why the crime rate in one area is higher at one time and lower at another. In this field, the following theories are used - economic, environmental (rational choice, routine activities, pattern of crime, safe space and broken glass), and also critical (leftism, realism). On the basis of these claims, it is believed that certain types of offence occur in specific places and at specific times. This is related to their specificity, which may result in an increased number of opportunities to commit crime due to the nature of the area. The theory of rational choice refers to the perpetrator's calculation of the cost of committing an offence. It states that criminals think rationally and make such decisions, they also consider danger and risk, and assess expected profit. In the case of routine activities, it is believed that the perpetrator chooses the victim during normal, daily activities such as commuting to work, coming back home or shopping. It means that $s /$ he does not go too far from well-known places. Thus, where there is a concentration of people motivated to commit a crime, the place may gain a distinctive character. The researchers who acknowledge this theory claim that the features of the place itself influence the number of offences committed (MORDWA 2013). This happens mainly in places where the concentration of people is high, closely related to mass tourists who as strangers are easy targets for local criminals. This group is more vulnerable to crime as they do not know the dangerous areas, and their vigilance is lower due to the holiday mood.

There is another theory, defined by B. PRIDEAUX (1996) as the tourism crime cycle, which assumes that the scale of crime is related to the way in which the place or the area is perceived. Thus, a hedonistic image of a destination results in a greater intensity in comparison to somewhere which represents and promotes family values (KANDY 2003).

The interest of academics and researchers proves that crime in or near tourist areas is an important issue. The conference 'Security and Tourism: developing global policies at the local level', organized within the European Forum for Urban Security was the capping of analyses and an attempt to answer questions about the relation between tourism and crime. The event was the culmination of the project 'Security and 
Tourism', which lasted 30 months (from 2013 to 2015), in which seven European cites took part - Alba, Barcelona, Brasov, Munich, Rome, Saint Denis, and Brussels. The main purpose of the project was to support the cities in improving the quality and effectiveness of tourism policy by including all aspects of security (https:/ / efus.eu).

\section{TOURISM AND CRIME: THEORETICAL DISCOURSE}

There is no doubt that tourism is often a 'driving force' for a given region, city or country. Tourism attractiveness is usually defined as a certain property of an area, a town or site which primarily consists of the tourism value, the degree of accessibility, and the level of tourist development (ROGALSKI 1972). However, it must be remembered that a sense of security is a very important factor when deciding a tourism destination in the contemporary world. According to P.E. TARLOW (2011), the high crime rate in some cities, identified as being against tourists (e.g. Rio de Janeiro), has led to a reduced number visiting the city. He also indicates that it has markedly affected the quality of citizens' lives. Thus, research in this field is crucial. The difficulty includes establishing the real number of offences and is connected with the fact that most crimes committed against tourists are not reported because (TARLOW 2011):

- most tourists are not immediately aware that they have become victims of crime, which pertains mostly to pickpocketing, as the vigilance of travellers is lowered during holidays;

- sometimes the victim does not know what to do after s/he has been attacked; does not know when the offence happened, where to go and whom to report it to. Thus, it is easier to forget about the matter, especially without knowledge of the local language;

- the victims are often convinced that they will not regain the stolen items so it is useless for them to report the incident.

What is more, many tourists become the victims of the crimes in which they take part as participants or provocateurs. In these cases, the desire to hide the event is not surprising, but leads to a lack of report, and lack of information in police statistics. Consequently, it is impossible to examine crime among tourists.

Tourist crime is defined in various ways. Some authors claim that perhaps some classifications of crime and violence committed in tourist destinations should be defined (PIZAM 1999), but this could be quite problematic. In a more concise and simple way, it is defined as crimes against tourists and visitors. Of course, the study of crime among tourists is not an easy task because none of the statistics separate offences committed against tourists from those against others. Tourists may become victims of crime, may be accomplices of various offences, and they may commit offences against the tourism infrastructure and personnel (TARLOW 2011). What is more, P.E. TARLOW (2011) points out that visitors who have become victims often consciously or unconsciously cooperate with offenders. Moreover, even if the victim has nothing to do with the crime, there are some social conditions, which predestine tourists to be particularly vulnerable. The table below (Table 1) presents different types of crime committed by various groups.

Table 1. Perpetrators and victims of crime

\begin{tabular}{|l|l|l|l|}
\hline $\begin{array}{c}\text { Crimes } \\
\text { committed } \\
\text { by: }\end{array}$ & \multicolumn{1}{|c|}{$\begin{array}{c}\text { Crimes } \\
\text { committed } \\
\text { against: }\end{array}$} & \multicolumn{1}{|c|}{ Examples } & Goal \\
\hline Tourists & $\begin{array}{l}\text { Other visitors, } \\
\text { local citizens, } \\
\text { personnel of } \\
\text { tourist services }\end{array}$ & $\begin{array}{l}\text { Burglary, theft, } \\
\text { robbery, } \\
\text { pickpocketing }\end{array}$ & $\begin{array}{l}\text { Mainly } \\
\text { economic }\end{array}$ \\
\hline Citizens & Visitors & $\begin{array}{l}\text { Assault, minor } \\
\text { theft, fraud, } \\
\text { petty crime }\end{array}$ & $\begin{array}{l}\text { Mainly } \\
\text { economic }\end{array}$ \\
\hline $\begin{array}{l}\text { Tourism } \\
\text { industry }\end{array}$ & Visitors & Economic fraud & Economic \\
\hline
\end{tabular}

Source: P.E. TARLOW (2011).

There is no doubt that tourist crime is directed against various groups. What is more, visitors may be drawn into illegal activities such as drug taking and use of psychoactive substances, participation in illegal events including prostitution, property damage, communication offences, minor and major theft, while in rare cases serious crimes such as murder. Such 'tourist criminals', if so-called, are 'professional', they know tourist behaviour well and they are aware that in most cases they will not be reported to the police. Tourists easily become victims or accomplices. Leaving their place of residence, tourists often leave their daily lives there, and travelling to new places, they mainly look to 'get away from reality', which results in weakened vigilance. The offenders can easily recognise the average visitor, and when s/he does not know the culture or the language, is vulnerable to becoming a crime victim. Additionally, tourists are often disorganized, which makes them an easy target for criminals.

Tourists and visitors are vulnerable to a wide range of offences, but some of them are proven to occur more often than others. Among the former there are mainly so-called distracted crimes. In this case, the offenders make use of tourists' distraction, their dis- 
organization caused by a change of place, new culture, and the necessity of dealing with strangeness. These include, but are not limited to pickpocketing, theft, fraud, luggage theft at airports, theft of documents and credit cards, as well as those making use of information technology e.g. identity theft (TARLOW 2011).

W. ALEJZIAK (1995) also points to the development of tourism and the frightening increase of crime risk and pathological incidents, and the general deterioration of public security. At the same time, he underlines that considering the development and growth of the importance of tourism, it is crucial for many cities to consider whether there is a connection between this development and the increased number of offences. The author says that there is no academic research which could determine whether tourism intensifies the negative phenomena. It is supposed that the inflow of a large group of people, in this case tourists, increasing the population of a given area, leads to a higher risk of crime. However, there is almost no research in this area. While research into these issues separately is considerable, there are no reports combining these two issues, which is crucial from a security perspective.

\section{TOURISM AND CRIME: RESEARCH REVIEW}

Polish research on the scale of crime in the tourism areas of cities, or on tourism crime in general, are almost non-existent. This section presents other research mainly in English and it seems that three thematic groups may be distinguished (Fig. 1).

THEMATIC GROUPS OF STUDIES ON TOURISM AND CRIME

Studies covering the general analysis of the impact of tourism on crime,the structure of crime in reception areas, the interdependence of both phenomena

Studies analysing potential impact of crime

in the areas of tourist reception on the economic development of the countries living off the tourism industry

Studies resulting from the research on tourists' perception of safety and the risk of crime, and the perception of the places, which are attractive

Fig. 1. An attempt to classify research concerning crime and tourism

Source: author

The first covers matters related to a general analysis of crime and tourism, which may be connected. The authors ask about the link between them, their relation- ship and their influence on each other. All discussion drifts towards similar conclusions, i.e. that it is difficult to determine that tourists are the victims of crime in areas of tourism reception; however, it may be concluded that there are some prohibited acts which concern them, and some regularities which may be found on the basis of analysis. A. PIZAM (1999) proposes a comprehensive typology of crimes committed mostly in various world tourism areas during the 1990s, based on 300 offences and acts of violence. His aim is to determine its influence on tourism demand, the effectiveness of counteracting methods and actions. In other research (1982), the author analyses the impact of tourism on the incidence of nine types of crime in 50 of the states of the United States. The research uses regression models, the influence of tourism on their occurrence, and also socio-demographic indicators. In the final conclusions, the author points out that in five out of ten offences analysed, tourism has no influence, while in the others numbers are very low; thus, the author considers them as irrelevant. On the other hand, W.V. PELFREY (2011) indicates that tourists and visitors constitute an important community in many countries and regions. However, there is little evidence that these groups are at higher risk of violence and property crimes in the cities which they visit. The study analyses the relation between numbers of visitors and their types, and patterns of criminal behaviour in two large cities subject to mass tourism. If simple dependencies are assumed, the number of crimes should be proportional to the number of visitors unless there are other strong determinants explaining the situation. Based on this, it is concluded that such dependence does not occur in any of the cities. Therefore, it is stated that the results obtained in this research could be helpful in examining the relationship between crime and tourism.

M. BARKER, S.J. PAGE \& D. MEYER (2002) examine the relation between tourism and crime at large sporting events. Their work presents the impact of the organization and course of a sporting event in Auckland, New Zealand on the crime rate, especially against tourists. Statistical models of tourism crime prove that there are no significant differences of numbers of victims between domestic and foreign tourists. Magnitude depends on ethnic origins or place of stay. However, tourists and local communities experience different types of crime. Foreigners are more likely to experience theft in places of entertainment and accommodation. Car theft is more common among domestic tourists. As a result, the study shows that the potential impact of crime connected with special events relates mostly to sudden changes in population and increased opportunities connected with a seasonal increase in tourism. Moreover, other factors related to events and places of tourist reception should be 
mentioned here. K. DE ALBUQUERQU \& J. MC KLROY (1999) claim that those visiting mass tourism destinations are more vulnerable to serious crimes than citizens. Similarly, it is stated that this group is at higher risk of common crimes such as theft whereas local people more often become victims of more serious crimes. The study does not show a positive correlation between numbers of victims and population density connected with increased tourism. However, the growing importance of crime against tourists for mass tourism in emerging Caribbean destinations is highlighted as a threat to the development of tourism in this region.

Another study was conducted by D.W. HARPER (2000), who analyzes the way in which thieves choose their victims from tourists. It concludes that it is according to a pattern constantly repeated. Tourists go to a variety of places, drink, have fun, lose their sense of danger, and being too relaxed often act carelessly because they believe that they are safe as they are on holiday.

In this group there are also works which draw conclusions regarding spatial factors in the occurrence of crime and its frequency. Attention should be paid to the work of B. BIAGI, M.G. BRANDANO \& C. DETOTTO (2012) in which the authors prove that in the long run tourism areas in Italy typically exhibit greater crime rates than areas of lesser tourism importance. Using econometric measures and the GMM system, they test whether tourist arrivals result in a general increase in the number of crimes. What is more, the extent to which tourists and citizens are exposed to crime is analyzed, but no significant results were found. At the end, the authors state that criminality is connected to tourism only in the case of large, crowded cities where there are many opportunities to commit crime, but the number of visitors does not influence it. E.L. GRINOLS, D.B. MUSTARD \& M. STAHA (2011) analyze the impact of visitors on the crime rate. They draw attention to the fact that it is often concluded that tourists influence this negative phenomenon and they have similar features which lead to these crimes. The results question this statement; however, mainly in the case of visitors to certain places, here national parks. It shows that the type of visit with regard to the type of attraction, as well as its attractiveness, may have significantly different effects on the image of crime in a particular area. Yet, another interesting elaboration is the work of R.W. GLENSOR \& K.J. PEAK (2004) which is a guide for local communities. The publication is a part of a series of guides, summarizing knowledge of how the police and law enforcement authorities deal with a reduction of the crime rate in various contexts. The issue here is devoted to tourism crime and includes its description and an analysis of the factors which influence the size of the problem. What is more, the authors propose a number of questions to the local community to help identify it and raise awareness of its scale. There is also a description of solutions which specific organizations make to prevent crime. Moreover, the guidebook presents information about offences committed in the United States, useful for those who deal with the issue outside Poland.

Another group of studies analyse specific tourism destinations, which allows the influence of crime on the state of local economies to be determined which are often based only on the tourist industry. On the other hand, threats to tourists from local communities are also presented, as well as from a lack of knowledge about local customs. In his work, P.A. BOURNE (2010) concentrates on the analysis of the image of crime in Jamaica in the eyes of the inhabitants. The research provides a review of the literature about the issues connected with the trust of local people toward tourists, and the security of tourists in which the tourism industry is one of the main economic sectors. The author raises the issue of the sense of self-protection of the inhabitants, and analyses the influence of a lack of trust (in interpersonal relations) on the development of tourism. He notices that it is disadvantageous from the perspective of economic and tourism development, very important for the Caribbean economy. The author also draws attention to the perception of security and self-defence by Jamaicans which may influence tourists' security. He underlines that misunderstandings in this matter may be reduced by closer acquaintance with the customs and habits of the inhabitants. Similar results are obtained by D. Alleyne \& I. BoxiLl (2003) in their research. They state that crime has a negative effect when it comes to a decision to go to Jamaica. R.G. OCHRYM (1990) analyzes crime and tourism on a slightly different level. The author concentrates on tourism destinations such as casinos and the cities in which they operate. He takes two states into consideration - New Jersey (where he analyzes two locations) and Nevada (the study is centred on Las Vegas). R.G. Ochrym examines how types of crime have changed since the beginning of tourism in Atlantic City and states that tourism destinations have average crime rates significantly different to urban areas; they are higher, at least in the case of Atlantic City. Tourism is also an important part of the functioning of New Orleans underlined by K.H. WILLIAMS (2010). The work covers an analysis of types, timings and numbers of crimes which were committed in New Orleans in comparison to other police districts, aiming to establish whether the tourism character determines a higher crime rate. The author points out that travel and the whole tourism industry have a great influence on the economy of New Orleans, which is negatively perceived because of its previously given title of the murder capital of the United 
States. He notices that police authorities do not register offences committed against tourists so the research is partially generalized. At the same time, it is proved that the increased number of police officers in areas of particular tourism concentration naturally leads to a reduction in the problem. Of course, it will not completely eliminate crime, especially against property, which occurs in tourism districts. This is due to the belief that tourists are lucrative targets, usually with significant sums of money and valuables. Besides that, they tend to be more relaxed and careless thus becoming victims.

All this research indicates the difficulty in explicitly stating that these phenomena impact on each other, but they raise important matters of interaction and threats from the two, often culturally different, sides.

The last group covers the results of research on perceptions of threats and safety among tourists. They mainly analyze the feeling of threat, depending on specific characteristics, but there are also theoretical considerations. A. HARRIOTT (2003b) studies the perception and fear of crime, and being a victim. He states that there are negative dependencies between these phenomena. On the basis of questionnaires, he shows that the 'best predictors' of fear are physical weakness, area of residence and professional status. The 'best predictors' of concerns are also physical weakness and the level of trust in the police. J. KING (2003) indicates that the sense of threat and security is based primarily on perception or having been a victim, but also on stories presented by the media based on economic and criminal statistics. T. BRUNT, R. MAMBY \& Z. HAMBLY (2000) presents the results of research on tourism and crime collectively, as there are indications that tourism contributes to crime. Moreover, there is an analysis of the results of research on being a victim and fear of crime among British tourists. Studies show that respondents are more likely to be victims of crime as tourists than as householders. It is also indicated that crime is not treated as the main problem during a holiday; the attention of a potential tourist is addressed to quite different issues. R. GEORGE (2010) concentrates on the perception of crime and the risk of becoming a victim in a particular tourism destination, Cape Town. He states that despite their own safety concerns, tourists do not give up returning. What is more, he shows that there are certain factors such as age, nationality and aim of the visit which determine the sense of security or threat. The sense of threat usually increases with age. Nevertheless, K.A. BOAKYE (2012) concludes in his work that providing an adequate sense of security for tourists is one of the most important duties of places or countries of tourism reception, often ignored because of the necessity of spending large sums of money. That is why, the self- awareness of tourists in the context of the conditions in their destination, is extremely important. According to the author, research on tourist safety is insufficient and there is relatively little. He tries to indicate the perspective of a tourist concerning security and protection in Ghana. He states that tourists feel most insecure in places with many tourist attractions in comparison to places of accommodation or to open space. Moreover, the presence of uniformed services does not influence the sense of security. It is also noted that fear of crime depends on socio-demographic factors (especially on age).

The last presents a slightly different view. S.F. SÖNMER (1998) who analyses the relationships between various factors and some important stages in making a decision about an international holiday. As a basis for his analysis, the author adopts theoretical frames for holiday decisions concerning the risk of terrorism. The study includes eight independent variables: international travel experience, risk perception, international travel attitudes, age, sex, education, income and the presence of children in a household. Dependant variables include the key steps in the decision-making process, i.e. the ease of making a general decision about international travel in comparison to making a decision about national travel, the scope of information sought, and the degree of security concern in assessing alternative destinations. As a result, he observes that attitudes toward international travel, risk perception and income have a direct impact on the choice of holiday destination outside the regular place of residence. Other elements, i.e. experience or education have only an indirect character. Another author, ALLEN (1999), analyses foreign tourists who became victims of crime in Australia. It is clearly stated that visitors there are at a low risk of crime. The most common offences experienced by tourists are harassment, intimidation and theft. However, in the conclusion, the author indicates that further research is needed so ratios could be compared between countries. M. KORSTANJE (2009) presents some theoretical considerations in this field. In his work, he is critical of the impact and constraints connected to taking risks in the context of the theory of perception in tourism. Additionally, he examines connections between threat, fear and anxiety in the same way. One of the issues raised by the author is the traveller's perception of risk. He distinguishes seven types, including those connected with travelling. According to the author, these are primarily concerns about health, terrorism and crime, but also natural disasters in tourism destinations.

As can be seen, there have been attempts to analyse the relation between tourism and crime. The analysed works deal with number of issues; however, there is still lack of research in this matter. 


\section{OVERVIEW OF THE RESULTS}

There is no doubt that both tourism and crime are common phenomena. Tourism is generally seen as positive, and is often a factor stimulating the economic development of countries, regions and cities. It has a positive impact on the material situation of societies. It is often indicated that it also contributes to the protection of nature and cultural monuments. The turn of the 70s brought the first studies which were critical towards tourism. Publications considered negative effects of the development of tourism, especially foreign arrivals, and they concern developing countries, i.e. so-called third world countries. W. ALEJZIAK (1995, p. 9) underlines that for these countries tourism is the easiest route to rapid development, overshadowing the negative influence on natural, social and cultural environments. The author (1999) notices that tourism, as an adventurous phenomenon, creates many opportunities to commit crime as tourists become somehow anonymous in a foreign environment. This results in a tendency to criminal or pathological acts. Besides that, the local community does not always enjoy the presence of strangers.
Although the negative effects of the development of tourism are visible, there is relatively little research analysing the issue. There is no doubt that works using English prevail in this respect. In Poland, the work of K. PRZECŁAWSKI (1983) deals with the problem of the negative effects of the development of tourism. W. BARTOSZEWICZ \& J. ŁACIAK (1989) analyse the impact of tourism on the natural, social and cultural environments of towns. Nevertheless, the lack of research, especially research concerning cities, is visible. Authors underline that results should be carefully interpreted. Criminal statistics rarely divide offences committed by tourists and those against them, making it difficult to indicate this group as really being at risk of crime. However, it is possible to indicate some predispositions of tourists, which favour a greater risk of certain offences. Moreover, it is underlined that there are more crimes in areas of mass tourism, connected to the periodic accumulation of people in a small area. Some research shows that sites of major attractions are relatively more dangerous in comparison to others. Potential offenders plan their illegal activities, knowing where people gather. However, the perception of risk and the sense of security depend on various

Table 2. Types of analysis with examples and conclusions

\begin{tabular}{|c|c|c|}
\hline Type & Example & General, chosen conclusions \\
\hline $\begin{array}{l}\text { General analyses of the } \\
\text { impact of tourism on } \\
\text { crime, crime in reception } \\
\text { areas, and their } \\
\text { interdependence }\end{array}$ & $\begin{array}{l}\text { PIZAM 1999, } \\
\text { DE ALBUQUERQU, } \\
\text { MCKLROY 1999, } \\
\text { PIZAM 1982, } \\
\text { PELFREY 2011, } \\
\text { BARKER, PAGE, } \\
\text { MEYER 2002, } \\
\text { HARPER 2000, } \\
\text { BIAGI, BRANDANO, } \\
\text { DETOTTO } 2012\end{array}$ & $\begin{array}{l}\text { - } \text { tourists may be easier targets for criminals than local inhabitants; } \\
\text { however, it cannot be indisputably confirmed; } \\
\text { - behaviour of tourists makes them a common target for theft; } \\
\text { - } \text { the influence of tourism is different for different types of crime; } \\
\text { - crime is linked to tourism more in big, crowded cities where there are } \\
\text { more opportunities; } \\
\text { - types of visit with regard to types of attraction, and level of } \\
\text { attractiveness, may have significant effects on the image of crime in } \\
\text { a particular area. }\end{array}$ \\
\hline $\begin{array}{l}\text { Analyses of the potential } \\
\text { impact of crime in areas } \\
\text { of tourist reception on the } \\
\text { economic development } \\
\text { of countries living off } \\
\text { the tourism industry }\end{array}$ & $\begin{array}{l}\text { BOURNE 2010, } \\
\text { OCHRYM 1990, } \\
\text { WILLIAMS } 2010\end{array}$ & $\begin{array}{l}\text { - the perception of safety with reference to the crime rate in various } \\
\text { tourism destinations has a great impact on the development of tourism } \\
\text { and the safety of tourists; } \\
\text { - cities with casinos or similar attractions tend to generate slightly higher } \\
\text { crime rates; } \\
\text { - an important element of shaping the image of a tourism destination is its } \\
\text { image as perceived by tourists. }\end{array}$ \\
\hline $\begin{array}{l}\text { Research on tourists' } \\
\text { perception of safety and } \\
\text { the risk of crime, and the } \\
\text { perception of sites which } \\
\text { are attractive, but at } \\
\text { the same time dangerous }\end{array}$ & $\begin{array}{l}\text { HARRIOTT 2003, } \\
\text { KING 2003, } \\
\text { SÖNMER 1998, } \\
\text { BRUNT, MAWBY, } \\
\text { HAMBLY 2000, } \\
\text { GEORGE 2010, } \\
\text { BOAKYE 2012, } \\
\text { KORSTANJE 2009 }\end{array}$ & $\begin{array}{l}\text { - fear among tourists is often dictated by the factors that affect levels } \\
\text { of anxiety; } \\
\text { - the sense of danger or safety primarily results from the perception, } \\
\text { the experience of being a victim, and the image created by the media; } \\
\text { - it is shown that most often attitudes toward international travel, risk } \\
\text { perception and income have a direct impact on the choice of holiday } \\
\text { destination outside the regular place of residence; } \\
\text { - tourists are more likely to become victims of crime, which is primarily } \\
\text { due to the fact that their attention is diverted away from crime and } \\
\text { security; }\end{array}$ \\
\hline
\end{tabular}


factors, among others on the experience of travel and age. On the other hand, knowledge of the risk of being a victim is slowly becoming one of the factors of choice. Most studies concentrate on the macro-scale, there is a lack of analysis concerning specific tourism areas in cities. Most research concentrates on countries or simply on the phenomenon itself and rarely relate and analyse the patterns in specific areas of cities.

\section{CONCLUSIONS}

On the basis of literature research, it is possible to indicate the following:

1) tourism is often an important part of national economies; thus, it is important to analyse what affects tourism, and what is generated by it, including what is negative;

2) aggregation of data enables research at the level of cities, regions and countries; however, there is a lack of data concerning smaller areas, e.g. specific tourism areas in cities;

3) problems related to the collection of criminal statistics result in relatively few works analysing the phenomena of tourism and crime;

4) most of the studies in this matter are in English;

5) existing works can be divided into three categories:

- studies covering a general analysis of the impact of tourism on crime, crime in reception areas, and their interdependence;

- studies analysing the potential impact of crime in areas of tourist reception on the economic development of the countries living off the tourism industry;

- studies resulting from research on tourists' perception of safety and risk of crime, and the perception of places which are attractive but at the same time dangerous.

6) studies usually refer to various tourist destinations and aspects; however, all tend to formulate general patterns, which in turn allows for a broad view of the problem.

A detailed summary and examples are presented in the Table 2.

\section{BIBLIOGRAPHY}

AlbuQUeRQU DE K., MCElROY J., 1999, Tourism and crime in the Caribbean, Annals Tourism Research, 26(4), pp. 968-994.

ALEJZIAK W., 1995, Turystyka a przestępczość i zjawiska patologii społecznej (zarys problematyki i koncepcja badań na przykładzie Krakowa), Folia Turistica, 5, pp. 97-27.
AllEN J., 1999, Crime against International Tourists, Crime and Justice Bulletin, 43, pp. 1-8.

ALLEYNE D., BOXILL I., 2003, Impact of crime on tourist arrivals in Jamaica: A transfer function analysis, [in:] A. Harriott (ed.), Understanding crime in Jamaica: New challenges for public policy, The University of the West Indies Press, Kingston, pp. 381-391.

BARKER M., PAGE S.J., MEYER D., 2002, Modeling tourism crime. The 2000 America's Cup, Annals of Tourism Research, 29, 3, pp. 762-782.

BARKER M., PAGE S.J., MEYER D., 2003, Urban visitor perceptions of safety during a special event, Journal of Travel Researc, 41(4), pp. 355-361.

BARTOSZEWICZ W., ŁACIAK J., 1989, Dwa punkty widzenia: gospodarcze i turystyki. Turystyka jako czynnik rozwoju społeczno-gospodarczego. Wyniki prac z lat 1986-87. Rocznik CPBP, Instytut Turystyki, Warszawa.

BIAGI B., BRANDANO M.G., DETOTTO C., 2012, The effect of tourism on crime in Italy: A dynamic panel approach, Economics Discussion Papers, 4, pp. 1-26.

BŁACHUT J., 2007, Problemy zwiazane z pomiarem przestępczości, Wolters Kluwer Polska, pp. 44-46.

BOAKYE K.A., 2012, Tourists' views on safety and vulnerability. A study of some selected towns in Ghana, Tourism Management, 33, pp. 327-333.

BOURNE P.A., 2010, Crime, tourism and trust in a developing country, Current Research Journal of Social Sciences, 2(2), pp. 69-83.

BRUNT T., MAWBY R., HAMBLY Z., 2000, Tourist victimisation and the fear of crime on holiday, Tourism Management, 21, pp. 417-424.

GEORGE R., 2010, Visitor perceptions of crime-safety and attitudes towards risk: The case of Table Mountain National Park, Cape Town, Tourism Management, 31, pp. 806-815.

GLENSOR R.W., PEAK K.J., 2004, Crimes against tourists, „ProblemOriented Guides for Police, Problem-Specific Guides Series", Gide no. 26, U.S. Department of Justice, pp. 1-54.

GRINOLS E.L., MUSTARD D.B., STAHA M., 2011, How do visitors affect crime, Journal of Quantitative Criminology, 27, pp. 363378.

HARPER D.W. jr., 2000, Planning in tourist robbery, Annals of Tourism Research, 27, 2, pp. 517-520.

HARRIOTT A. (ed.), 2003, Understanding crime in Jamaica: New challenges for public policy, The University of the West Indies Press, Kingston.

KANDY J., 2003, Crime, [in:] J. Jenkins, J. Pigram (eds.), Encyclopedia of Leisure and Outdoor Recreation, Taylor \& Francis, pp. 86-88.

KING J., 2003, Perception of crime and safety among tourists visiting the Caribbean, [in:] A. Harriott (ed.), Understanding crime in Jamaica: New challenges for public policy, The University of the West Indies Press, pp. 159-170.

KORSTANJE M., 2009, Revisiting risk perception theory in the context of travel, e-Review of Tourism Research, 7, 4, pp. 68-81.

MORDWA S., 2013, Przestępczość i poczucie bezpieczeństwa w przestrzeni miasta - przykład Łodzi, Wyd. Uniwersytetu Łódzkiego, Łódź.

OCHRYM R.G., 1990, Street crime, tourism and casinos: An empirical comparison, Journal of Gambling Studies, 6, 2, pp. 127-138.

PELFREY W.V., 2011, Tourism and crime: A preliminary assessment of the relationship of crime to the number of visitors at selected sites, International Journal of Comparative and Applied Criminal Justice, 22, 2, pp. 293-304.

PIZAM A., 1982, Tourism and crime: Is there a relationship?, Journal of Travel Research, 20(3), pp. 7-10. 
PIZAM A., 1999, A comprehensive approach to classifying Acts of crime and violence at tourism destinations, Journal of Travel Research, 38, 1, pp. 5-12.

PRIDEAUX B., 1996, The tourism crime cycle: a beach destinations case study, [in:] A. Pizam, Y. Mansfield (eds.), Tourism, crime and international security issues, John Wiley, Chichester, pp. 59-76.

PRZECŁAWSKI K., 1983, Turystyka jako czynnik przemian społeczno-kulturowych środowiska, Problemy Turystyki, 1/2.

ROGALEWSKI O., 1972, Podstawy gospodarki przestrzennej w turystyce, Zakład Graficzny Politechniki Warszawskiej, Warszawa.

SÖNMER S.F., 1998, Influence of terrorism risk on foreign tourism decisions, Annals of Tourism Research, 25(1), pp. 112-144.
SZTAUDYNGER M., 2004, Ekonometryczna analiza przestępczości w ujęciu terytorialnym, Wiadomości Statystyczne, 12, pp. 5360.

TARLOW P.E., 2011, Crime and Tourism, [in:] J. Wilks, D. Pendergast, P. Leggat (eds.), Tourism in turbulent time (Towards Safe Experience for Visitors), pp. 93-101.

WiLLIAMS K.H., 2010, An Analysis of crime statistics to tourist areas and non-tourist areas in New Orleans, Caesars Hospitality Research Summit, 10, pp. 1-9.

https://efus.eu/en/topics/places-and-times/tourism/newssecurity-tourism/efus/9722/; 1.07.2017.

Article received:

12 April 2017

Accepted:

14 June 2017 